
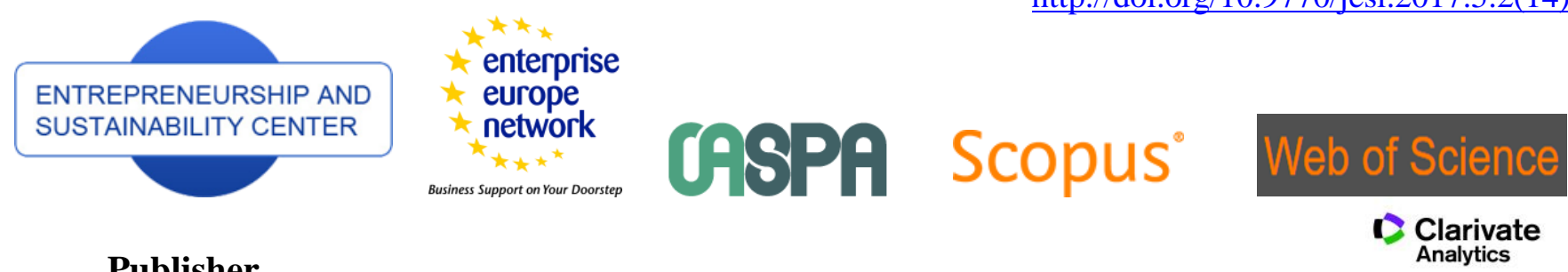

Publisher

$\underline{\text { http://jssidoi.org/esc/home }}$

\title{
ENTREPRENEURSHIP ECOSYSTEM FACETS: THE EUROPEAN MIGRANT CRISIS AND PUBLIC OPINION IN SLOVAKIA
}

\author{
Marcel Lincényi \\ Department of Political Science, Alexander Dubcek University of Trencin, \\ Slovak Republic 2 Studentska Str., Trencin, 91150, Slovak Republic \\ E-mail: $\underline{\text { marcel.lincenyi@ tnuni.sk }}$
}

Received 18 May 2017; accepted 26 September 2017; published 29 December 2017

\begin{abstract}
The research study offers an analysis of the current Slovak public opinion on the issue of migration in the context of the current refugee crisis, while also offering prevailing opinions, attitudes, preferences and values of the Slovaks to the possible arrival of asylum seekers in Slovakia. The study also provides the Slovak citizens' opinions on possible solutions to the refugee crisis. From realized analysis public opinion of the citizens has emerged with serious stance on the issue of migration. It should be noted that a similar approach is also seen in other countries of the Visegrad Group. We think that improving public opinion on citizens' attitudes regarding migration would demand the politicians an educating campaign not only in Slovakia but across the whole European Union. The European Commission may need to promote multicultural education.
\end{abstract}

Keywords: entrepreneurship ecosystem, European migrant crisis, refugee, Slovak Republic, research, public opinion

Reference to this paper should be made as follows: Lincényi, M. 2017. Entrepreneurship ecosystem facets: the European migrant crisis and public opinion in Slovakia, Entrepreneurship and Sustainability Issues 5(2): 357-367. http://doi.org/10.9770/jesi.2017.5.2(14)

JEL Classifications: N44, O15, Y80,

Additional disciplines political sciences; sociology; information and communication;

\section{Introduction}

Since 2013, the European migration and asylum regime has entered a phase of crisis, which reveals the deep interdependencies between its different components (including intra-EU mobility) and the unbalanced nature of its normative foundations. This original structural fragility had not fundamentally compromised the overall functioning of the regime until two major exogenous factors (the economic crisis, with its asymmetrical impact on the eurozone, and the wave of political instability and conflicts on the southern shore of the Mediterranean) brought its intrinsic limits to the point of rupture (Pastore, Henry, 2016, 44-57).

In 2015, over one million refugees and migrants arrived in Europe, laying bare the limitations of the EU's common border control and burden-sharing systems. „It explains how unilateral, national-level responses have made the EU as a whole particularly susceptible to a unique brand of coercive bargaining that relies on the 
threat (or actual generation) of mass population movements as a non-military instrument of state-level coercion " (Greenhill, Kelly 2016, 317-332).

The number of refugees and migrants arriving by sea in Europe is on the rise. According to UNHCR, more than one million refugees and migrants arrived in Europe by sea in 2015, whereas more than 3700 people lost their lives while trying to reach the European shores. As a response to the migration crisis, the EU has adopted a number of policies as proposed by the European Commission in the Ten point Action Plan on Migration and the European Agenda on Migration. This was followed by adoption of the second implementation package of the Agenda and initiation of EU-Turkey Joint Action Plan on migration management (Ineli-Ciger, Meltem, 2016, 1$33)$.

We address the Mediterranean borders as they really are at the current moment: interconnected, delocalized, much more extensive than defined by law as "the European frontier". They constitute a "pressure cooker", exacerbated by the effects of police controls in transit countries like Morocco, Libya and Turkey. „, This border Regime extends to the European territory contains through the 400 immigration detention centres and the monitors of foreigners settling in Europe. The overwhelming borderland regime calling into question the validity of the ethical and political principles that led to the construction of the European Union " (Suarez-Navaz, Liliana, 2015, 265-276)

Although migration was not at first among the Barcelona Process priorities, this mechanism regulated it in an indirect way. The Process was supposed to reduce emigration from the Mediterranean countries through their development, which had to create a wide range of opportunities for their population. „These events also showed the failure of the EU migration policy in the region since illegal migration is still growing. Today it is essential for the European Union to analyse the shortcomings of the Barcelona Process and reform its policy towards the Mediterranean region“ (Pogorelskaya, Anastasia, 2016, 103-107)

Margarita Urda and Svetlana Shevelyova (2016, p. 22) discuss some pending issues related to migration in terms of ensuring national security of the countries involved in international integration processes; it is emphasized that security challenges are closely related with the formation and implementation of migration policy. „The preconditions of forced and illegal migration types are identified together with their influence on the security state in different spheres of social life. It is shown that intensification of migration processes may have a very good economic effect and can be justified economically and politically“. (Margarita, Shevelyova, 2016, 22) „It has been determined that money transfer remittance of migrants, which also affects one of the basic macroeconomic indices, such as gross domestic product, has a considerable impact on sustainable economic development of both states“ (Grinko, 2016, 27).

\section{Methodology}

The main objective of the research is to analyze the current Slovak public opinion on the issue of the European migrant crisis.

One of the secondary research objectives is to analyze opinions, attitudes, preferences, values of the Slovaks in the face of the possible arrival of refugees in Slovakia.

Another secondary objective is to analyze opinions of the Slovaks to come up with a possible solution of the European migrant crisis.

In determining the methodology of research, we have set the following research questions with which we continue to work: 
Research question no. 1: What is the attitude of citizens of the Slovak Republic to the possible arrival of asylum seekers in the Slovak Republic in connection with the migration crisis?

We anticipate the concerns of citizens of the Slovak Republic about the possible arrival of asylum seekers and on the ground that Slovakia is a conservative country where significant national and Christian principles, and the Slovaks have a lot of experience with migrants. As it has been clear from research studies that was implemented by the International Organization for Migration (IOM) in Bratislava within the project Migration in the Slovak Republic to the EU (2004 - 2008), foreigners living in Slovakia have perceived stereotype attitudes towards them which are based on rigid and hardly changing prejudices against otherness. Compared with their counterparts from other EU countries are citizens of Slovakia is relatively little experience with foreigners and is also very low level of knowledge about groups of foreigners living in Slovakia. (Vašečka, 2009, 105-106) It should also be said that the attitude of the Slovaks to the possible arrival of asylum seekers in Slovakia certainly influenced the politicians who have done on this subject campaign in parliamentary elections in 2016. On the other hand, some entrepreneurs and other managers could welcome migrants from a new workforce perspective. According to the authors Grenčíková, Španková and Habánik (2017, 81-89), labour force is beginning to be a serious problem for the economy of the Slovak Republic and Czech Republic.

Research question no. 2: How should the EU deal with the issue of migration, concerning the Slovaks?

We think that Slovaks will prefer such solutions the European Union to the issue of migration that is not their individual concern.

The research survey was conducted in the fourth quarter 2015 The sample of respondents in 1033, which was representative of the population in terms of gender, age and region. The research sample consisted of 492 men and 541 women.

For data collection questionnaire was used as the main research method. Administered questionnaire was provided by 100 interviewers trained and experienced personnel in the field, and had a 100 percent return. The questionnaire consisted of 17 closed, open, semi-closed and items that provide options for quantitative and qualitative processing. In the case of closed items were used three types of questions: dichotomous offer simple choice and a multiple selection. Questionnaire method was also combined with the method Likert scale. (Gavora et al., 2010)

\section{Results and Discussion}

Only $7.6 \%$ of all respondents believe that refugees can contribute to Slovakia. In contrast, only $75.5 \%$ of respondents were concerned that the arrival of asylum seekers in Slovakia may increase crime. More Graph 1. 


\section{Graph 1: Do you think that refugees can contribute to Slovakia?}

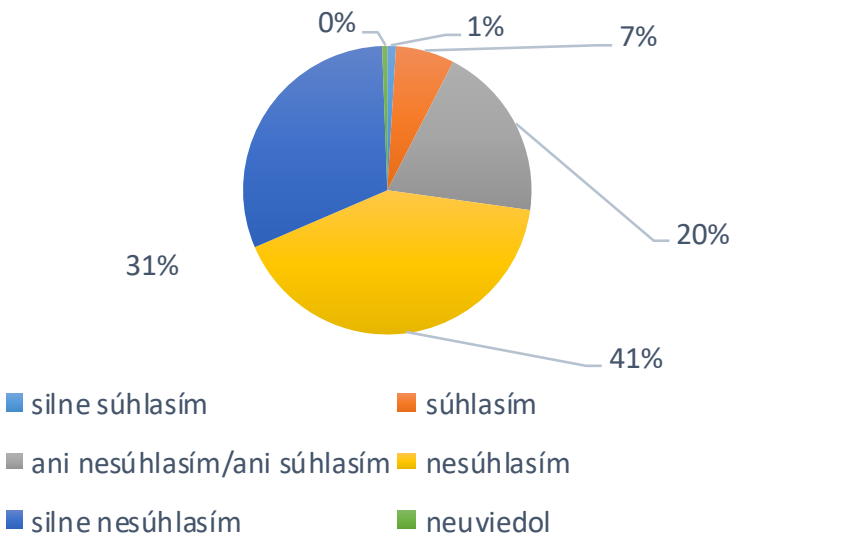

\section{Graph 1.}

Source: Own processing of field research documents

Most Slovaks polled $82.55 \%$ disagree with the fact that refugees gain permanent residence in Slovakia. Up to $76.5 \%$ of all respondents are in fact concerned that refugees are unable to comply with Slovak traditions and norms. More Graph 2.

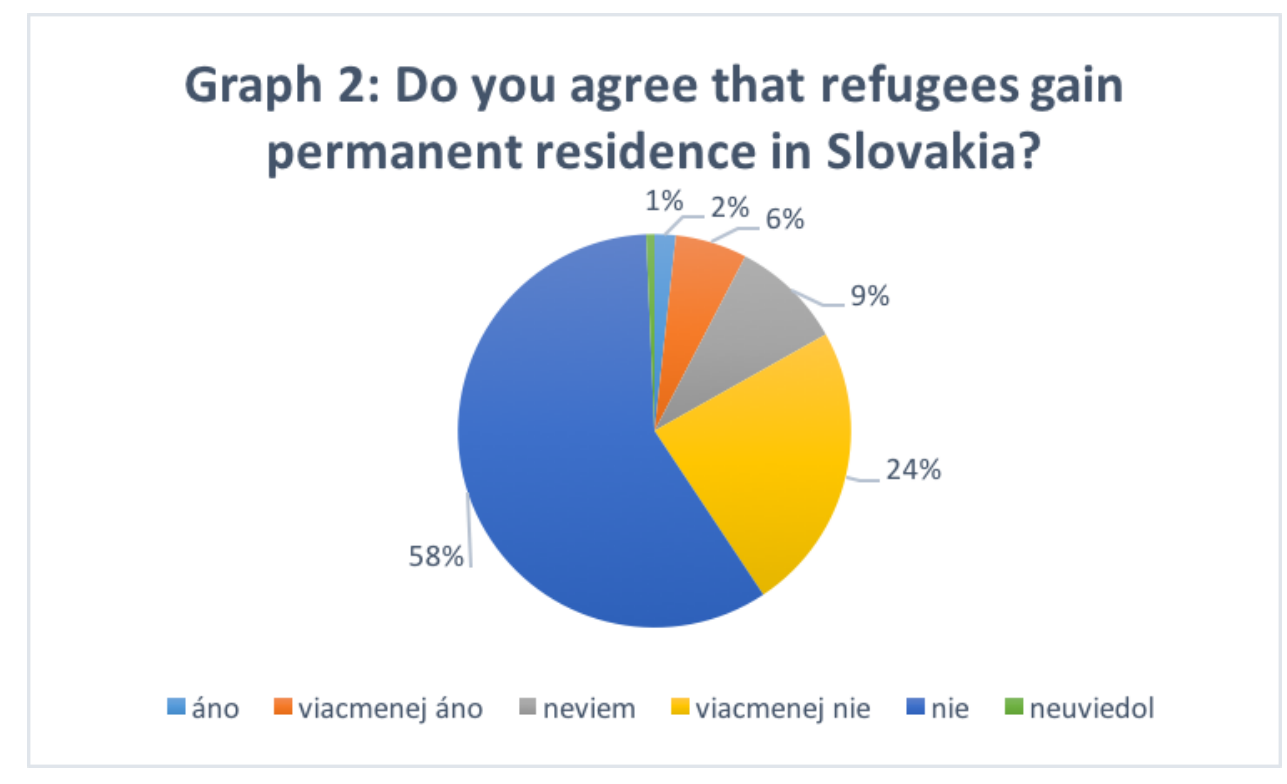

\section{Graph 2.}

Source: Own processing of field research documents

Slovaks, however, were not willing to accept some of the habits of migrants (80.3\% of respondents) that asylum seekers raised with their arrival in Slovakia. Almost half of respondents would be unemployed refugees in their 
companies, while $22.6 \%$ of those questioned can imagine it, and the remaining respondents to this question could not answer. In contrast, more than half of those surveyed would be willing to change their minds if it happens that mothers came with their children to Slovakia. (53\%) More Graph 3.

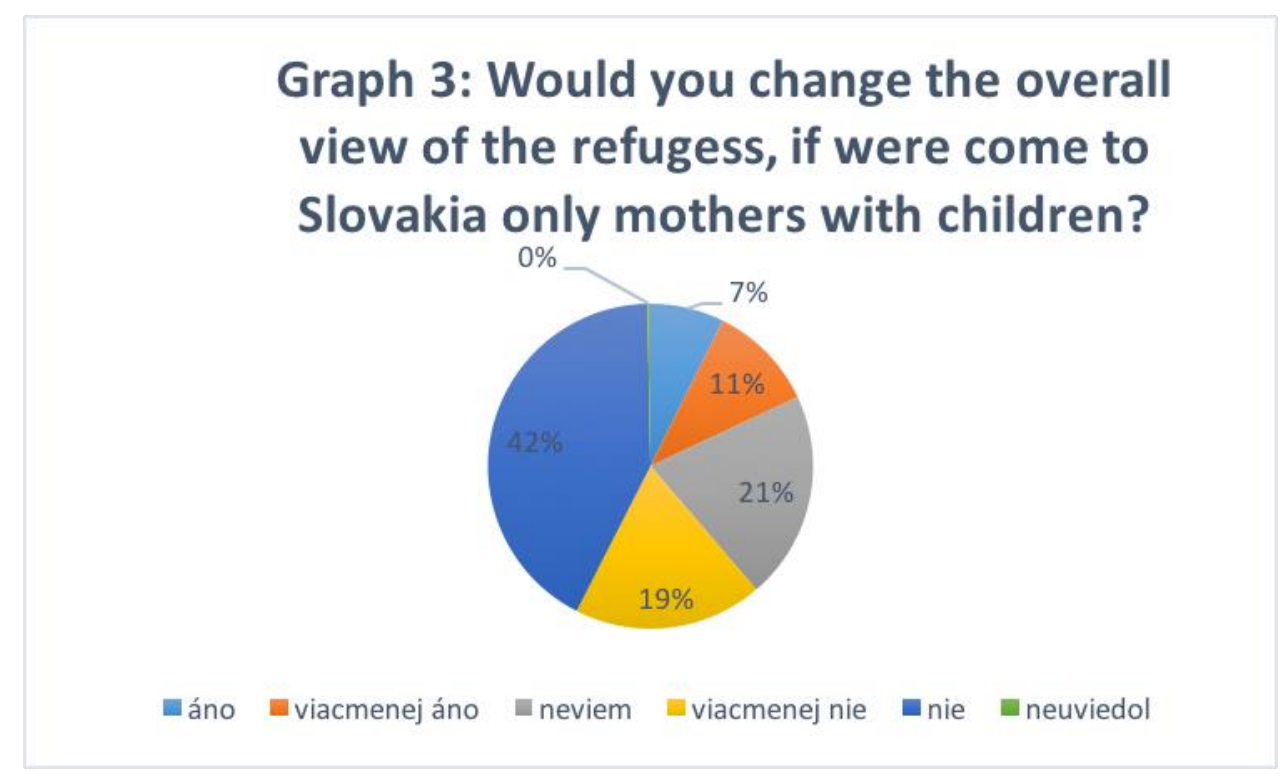

\section{Graph 3.}

Source: Own processing of field research documents

Slovaks would not want to live next to the asylum seeker. Most respondents (70.6\%) would be impeded if they were in their area opened refugee facilities, and only $88.2 \%$ of those questioned did not wish to see mosques flourishing in their city. More graph 4.

\section{Graph 4: Would you prefent if opoened refugee facilities in your neightborhood?}

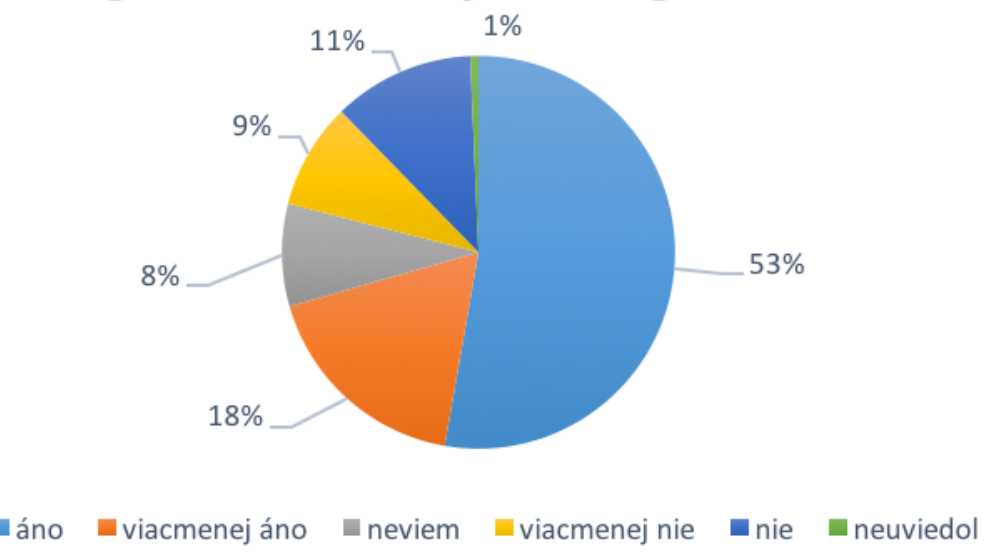

\section{Graph 4.}

Source: Own processing of field research documents. 
Up to $76.8 \%$ of all respondents think that mandatory quotas for the distribution of refugees in the EU do not help resolve the situation with immigration. Moreover, according to $81.9 \%$ of respondents at all it is not right for the EU to dictate to Member States refugee quota. The most effective solution refugee crisis is to fight against its causes, namely wars and terror in Syria and Iraq. This argument has been supported by $63.3 \%$ of respondents. Up to $67 \%$ of those surveyed considered the correct decision by the Government of Robert Fico, the Slovak Republic will respect the quota and an action before the European Court of Justice in Luxembourg against the Council of the European Union. More graph 5-8.

\section{Graph 5: Mandatory quotas for the distribution of refugees within the EU to help solve immigration:}

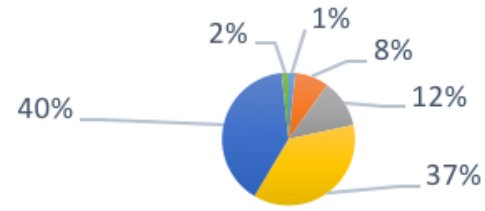

$$
\begin{aligned}
& \text { घilne súhlasím } \quad \text { súhlasím } \\
& \text { অ ani nesúhlasím/ani súhlasím } \text { nesúhlasím } \\
& \text { घilne nesúhlasím aneuviedol }
\end{aligned}
$$

\section{Graph 5.}

Source: Own processing of field research documents.

\section{Graph 6: Do you agree that the EU to member states to distate mandatory quotas?}

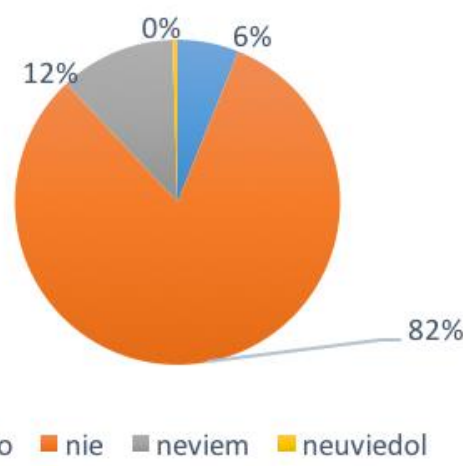

Graph 6.

Source: Own processing of field research documents. 


\section{Graph 7: Government R. Fico decision, the Slovac republic will not respect quotas and bring a court action, consider:}

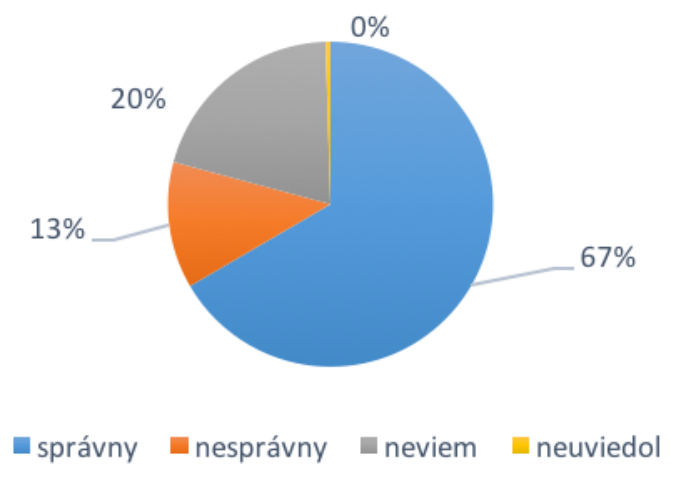

Graph 7.

Source: Own processing of field research documents.

\section{Graph 8: What measure (s) would be most effective in addressing the refugee crisis?}

povinné kvóty

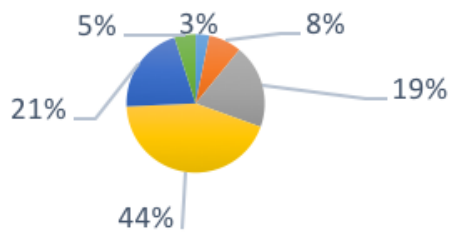

- finančná pomoc nárazníkovým krajinám

चabránit' prevádzačom dostat' utečencov do Európy

E boj proti príčinám utečeneckej krízy, vojnám, a teroru v Sýrii a Iraku

- obnovenie kontrol na hraniciach

\section{Graph 8.}

Source: Own processing of field research documents.

The European Union should take particular those migrants who, forced to flee the home armed conflicts. They think that $61.3 \%$ of respondents in the survey. Only $11 \%$ of the respondents agree with the adoption of asylum seekers in the case of religion, $10.2 \%$ for political reasons, and only $6.8 \%$ for economic reasons. Others have said quite the adoption of migrants, respectively, have not decided to answer. More Graph 9. 
ENTREPRENEURSHIP AND SUSTAINABILITY ISSUES

ISSN 2345-0282 (online) http://jssidoi.org/jesi/

2017 Volume 5 Number 2 (December)

http://doi.org/10.9770/jesi.2017.5.2(14)

\section{Graph 9: EÚ should adopt only those refugess who, forced to flee the home:}

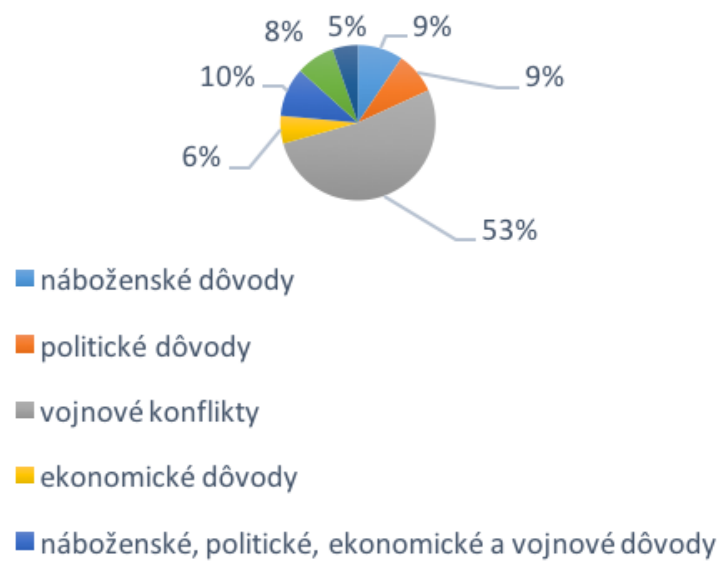

Graph 9.

Source: Own processing of field research documents.

In the first research question, we assumed the concerns of citizens of the Slovak Republic about the possible arrival of asylum seekers and on the ground that Slovakia is a conservative country where significant national and Christian principles, and the Slovaks have a lot of experience with migrants. This argument is confirmed by eight of the nine studied questions in the questionnaire. Migrants as interviewed by the Slovaks were not important, but rather a burden because they would not be willing to respect local traditions and standards and contribute to increase crime. Slovaks who were interviewed disagree in various ways with the refugees obtaining permanent residence in Slovakia upon arrival, they would live next to the migrant, however, they would not employ the imigrants at work and would not want to be close to them or allow them to grow mosques. Slovak citizens would also not be willing to accept some of the habits of migrants that asylum seekers would introduce upon their arrival in Slovakia. On the other hand, it is interesting that the Slovaks would be willing to change their minds on the issue of migration if only mothers come with their children to Slovakia.

In the second research question we observed that the Slovaks will prefer such solutions that the European Union introduces to the issue of migration if the solutions are beyond their individual concern. The interviewed Slovak citizens do not agree with mandatory quotas for the distribution of refugees in the EU as well as the dictation of these quotas upon their states, the EU Member States, while not respecting these quotas believe finding solutions to the issue is correct. They think that migration policy should be able to limit those asylum seekers who, were being forced to flee their homes due to armed conflicts. According to the interviewed respondents the most effective solution to the refugee crisis would be possible by finding the cause, which is the combination of wars and terror in Syria.

We think that the critical attitude of the Slovaks towards the European Union's solutions is also related to the Euroscepticism and the negative moods that rise in the European Union from the economic crisis. (Fabus 2012) and the subsequent decline in confidence in the European Union (Zsuzsanna, Mura 2014), which is confirmed by Eurobarometer surveys in several Member States. 
ENTREPRENEURSHIP AND SUSTAINABILITY ISSUES

ISSN 2345-0282 (online) http://jssidoi.org/jesi/

2017 Volume 5 Number 2 (December)

http://doi.org/10.9770/jesi.2017.5.2(14)

Similar results of research studies have also been typical to other polls. Public opinion poll on public attitudes towards refugees 2Muse Agency Initiative Call for humanity pro bono have confirmed a slight majority against refugees that there was bias and little has been done by the government. To the question "Do you agree that Slovakia adopted refugees and could thus become their new home country?" The response was "no" by $56 \%$ of the population, the portion that agreed with the adoption was $(18 \%)$ and those who withheld to express their opinion were (26\%). As indicated in the survey, which took place from 09.09 to 12/09/2015 in Slovakia on a representative sample of the population 15+ (representatives in terms of gender, education, age, size and region of residence), most of the concerns (60\%) can be summed up under the category Aggregates security and cultural maladjustment. It should also be noted that fears about asylum seekers in Slovakia apply to the Visegrad Group countries and the politicians need to explain to the citizens this unpopular topic.

\section{Conclusions}

The completed analysis shows cautious attitude of citizens towards the issue of migration. We think that the concerns of citizens compounded negative posts in the media, as well as some politicians utilized the issue for their advantage during the election campaign in the parliamentary elections in 2016, who, instead of responsibly explaining the problem of migration to the negative statements made it a tool for election campaign.

We believe that to improve public opinion on the issue of migration would help awareness campaign in the mass media with the help of using marketing communication. Of course, this marketing campaign should be carried out not only in Slovakia, but throughout the European Union under the coordination of the European Commission. (See marketing campaign Polakevičová 2016; Szabo 2016; Machová, Huszárik, Toth 2016).

Several experts also highlight the importance of multicultural education in the case of increasing the tolerance of citizens to asylum policy (Dopita, Staněk 2007; Medved’ová 2008; Janas 2015).

The study does not claim of bringing comprehensive insight into the analysis of Slovak public opinion on the issue of migration. However, the topic that has been covered above offers some insights and treatment options. First of all, it will be very interesting to analyze public opinion on the issue of migration with regard to the Slovaks after some time now during the Slovak Presidency of the Council of Europe, respectively, after the actual year of feasibility study. Additionally, it would be interesting to carry out in-depth interviews with selected citizens about the causes of fear of the refugee crisis among others.

\section{References}

Dopita, M., Staněk, A. eds. 2007. Multikulturalita a výchova k občanství [Multiculturalism and Citizenship Education]. Praha: Nakladatelství Epocha, 272 p, ISBN 978-80-87027-37-0.

Grinko, I. 2016. International migration of labour resources of Ukrajine and Bulgaria: impact on sustainable economic development of both countries, Economic Annals 160(7-8): 27-30. Avalaible on the Internet: http://soskin.info/userfiles/file/Economic-Annals-pdf/DOI/ea$\underline{\mathrm{V} 160-05 . p d f}$

Gavora, P. et al. 2010. Elektronická učebnica pedagogického výskumu [Electronic textbook of pedagogical research]. Bratislava: Univerzita Komenského, 2010. Avalaible on the Internet: http://www.emetodologia.fedu.uniba.sk/ ISBN 978-80-223-2951-4.

Greenhill, K. M. 2016. Open arms behind barred doors: fear, hypocrisy and policy schizophrenia in the European migration crisis, European Law Journal 22(3):317-332. https://doi.org/10.1111/eulj.12179 
ENTREPRENEURSHIP AND SUSTAINABILITY ISSUES

ISSN 2345-0282 (online) http://jssidoi.org/jesi/

2017 Volume 5 Number 2 (December)

http://doi.org/10.9770/jesi.2017.5.2(14)

Grenčíková, A., Španková, J., Habánik, J. 2017. Regional disparities in labor force migrationbroad in Slovak republic and in Czech Republic, Economics \& Sociology 10(3): 81-89 https://doi.org/10.14254/2071-789X.2017/10-3/6

Fabuš, M. 2012. The application of oca criteria on the European monetary union. 9th International Conference on European Financial Systems 2012 Location: Brno, Czech republic, Date: Jun 21-22, 2012, p. 41-44, WOS:000316422800007, ISBN:978-80-210-5940-5

Ineli-Ciger, M. 2016. Time to activate the temporary protection directive why the directive can play a key role in solving the migration crisis in Europe, European Journal of Migration and Law 18(1): 1-33 https://doi.org/10.1163/15718166-12342088

Janas, K. 2015. Crisis Management in the Slovak Republic (State Administration). MERCUR VERLAG, ISBN 978-3-9504054-2.2.

Medved'ová, G. 2008. German's Minority's Identity in the Czech Cultural Environment within 1918-1938. Life Image in Literature. In STANĚK, A. (ed.) Multikulturní výchova jako možná cesta ke vzájemnému poznávání a pregraduální př́prava učiteli̊ [Multicultural education as a possible way of mutual learning and undergraduate teacher training]. Praha: Nakladatelství Epocha, s.r.o., (pp. 133-145). ISBN 978-80-87027-83-7.

Machová, R., Huszárik, E.S., Tóth, Z. 2016. Is advertising innovation the same as shocking? In Journal of Applied Economic Sciences, 11 (2): 247-250, ISSN: $1843-6110$

Naumovska, L.; \& Bogdan, S. 2015. Integrated multigenerational marketing communications: A modern market indrustry challenge. Skopje: University of tourism and management. In: International conference "2015 Icon BEST, Economic analysis of global trends in tourism, finance, education and management." ISBN 978-608-4593-48-5.

Pastore, F.; Henry, G. 2016. Explaining the Crisis of the European Migration and Asylum Regime, International spectator 51(1): $44-57$. https://doi.org/10.1080/03932729.2016.1118609

Pogorelskaya, Anastasia M. 2016. The Barcelona process and its relevance to the current immigration crisis in the EU, Tomsk State University Journal 403: 103-107. Avalaible on the Internet: https://doi.org/10.17223/15617793/403/17

Polakevičová, I. 2016. Controversy of media discourses in (a) political campaigns to referendum for protection of family 2015 in media space in Slovakia, European Journal of Science and Theology 12(1): 11-19. http://www.ejst.tuiasi.ro/Files/58/2_Polakevicova.pdf

Urda, M., \& Shevelyova, S. 2016. Migration policy and national security challenges in globalization conditions, Economic Annals 157(34): 22-24. Avalaible on the Internet: http://soskin.info/userfiles/file/Economic-Annals-pdf/DOI/ea-V157-0006.pdf

Suarez-Navaz, L. 2015. Migration and refuge in the Mediterranean, beyond borders. Revista de dialectologia y tradiciones populares 70 (2): 265-276. https://doi.org/10.3989/rdtp.2015.02.001.01

Szabo, P. 2016. Possibilities and limits of text strategies in the political marketing, European Journal of Science and Theology 12(1): 193203 Avalaible on the Internet: http://www.ejst.tuiasi.ro/Files/56/18_Szabo.pdf

Toth, Zsuzsanna, Mura, Ladislav. 2014. Support for small and medium enterprises in the economic crisis in selected eu countries. In: 12 th International Conference on Hradec Economic Days (HED 2014): Economic Development and Management of Regions Location: Univ Hradec Kralove Dept Econ, Hradec Kralove, Czech Republic Date: Feb 04-05, 2014, p. 424-429, 2014. WOS:000398250400053, ISBN:978-80-7435-370-3

Vašečka, M. 2009. Postoje verejnosti k cudzincom a zahraničnej migrácii v Slovenskej Republike [Attitudes of the public to foreigners and foreign migration in the Slovak Republic]. Bratislava: IOM Medzinárodná organizácia pre migráciu. ISBN 978-80-970307-0-4.

V minulom roku ušlo pred vojnami rekordných 60 miliónov l'udí [Last year, a record 60 million people were killed]. 2016 [online] accessed [4.7.2016] Avalaible on the Internet: http://europskenoviny.sk/2016/06/28/minulom-roku-uslo-pred-vojnami-rekordnych-60milionov-ludi/

Čo si myslia l'udia o utečencoch? (Výsledky prieskumu verejnej mienky). [What do people think of refugees? (Results of opinion polls)] 2015 [online] accessed [4. 7. 2016] Avalaible on the Internet: https://dennikn.sk/blog/co-si-myslia-ludia-o-utecencoch-vysledky-prieskumu-verejnej-mienky/ 
ENTREPRENEURSHIP AND SUSTAINABILITY ISSUES

ISSN 2345-0282 (online) http://jssidoi.org/jesi/

2017 Volume 5 Number 2 (December)

http://doi.org/10.9770/jesi.2017.5.2(14)

Doc. PaedDr. PhDr. Marcel LINCÉNYI, PhD. he has been working at Alexander Dubček University of Trenčín since October 2010, at that time he is the deputy head of the department of political science for pedagogy, science and research. As a journalist, she also has practical experience from several national media. His research and research intention is focused mainly on the research of the symbiosis of politics and the media (analysis of media content, the influence of the media on society), analysis of European political communication, realizing this research not only from the point of view of the mass media communication discipline but also analyzing the problem from a multidisciplinary point of view, social sciences and marketing as a subgroup of economic sciences. Evidence of his scientific research is the publication of research studies on the subject in domestic as well as foreign scientific and professional periodicals and presented contributions at domestic as well as foreign scientific conferences and seminars.

ORCHID ID: orcid.org/0000-0002-9076-026X

Register for an ORCID ID:

https://orcid.org/register

Copyright (C) 2017 by author(s) and VsI Entrepreneurship and Sustainability Center

This work is licensed under the Creative Commons Attribution International License (CC BY).

http://creativecommons.org/licenses/by/4.0/

c) (i) Open Access 